\title{
Study of Physical and Chemical Parameters of Nahr Al Bared River, North Lebanon
}

\author{
Dunia Bouaoun* and Rony Nabbout \\ Department of Chemistry, Faculty of Sciences II, Lebanese University, Jdeidet el Matn, Lebanon
}

\begin{abstract}
In assessing the environmental status and detecting the signs of pollution during the dry season in Nahr alBared River, at the North of Lebanon, several parameters have been studied to detect physical-chemical pollution in this river. Surface water analysis was run monthly for a period of 7 months, from April till October 2015, along 7 stations (A1 to A7) that extend from Ras el Ain in the East, to Mediterranean Sea in the West. During this period, the temperature followed its normal cycle usually noted in the Lebanese coastal waters; salinity varied spatially and temporally presenting sometimes low or high values due to the river's inputs or low level of water in the river. Significant fluctuations of ionic concentrations were observed in most of the stations and during the period of this study. High levels of calcium (156 mg.L-1) were observed at stations located at station 6 in April. However, Magnesium concentrations were low in April and very high in all stations in August. High levels of sulfates (198.7 mg. $\left.\mathrm{L}^{-1}\right)$ were detected at station A4 in August. The high level of carbonates concentration at some stations has caused an important increase in the $\mathrm{pH}$ (from 7.2 to 9). Nitrate concentration changed in every station, $4.34 \mathrm{mg.L} \mathrm{L}^{-1}$ to $9.3 \mathrm{mg} . \mathrm{L}^{-1}$ reacting with the man-made disturbance such as agricultural activities. Heavy metals concentrations have been under the limit, in accordance with the method of detection by atomic absorption spectrophotometer. Consequently, the values of physical-chemical parameters can be considered good indicators to assess the environmental status of the sites.
\end{abstract}

Keywords: Lebanese coastal waters; Akkar; Nahr al-Bared River; Environment status assessment; Physical-chemical parameters; Heavy metals

\section{Introduction}

Lebanon extends over $210 \mathrm{~km}$ along the coast and $50 \mathrm{~km}$ inside. It is located along the Eastern Mediterranean basin. The total area is $10452 \mathrm{~km}^{2}$.

Lebanon climate is typically Mediterranean with strong rainfall in winter (January to April), dry to very dry during the remaining months of the year.

Average annual temperatures are $20^{\circ} \mathrm{C}$ on the coast, $16^{\circ} \mathrm{C}$ in the Bekaa Valley, and below $10^{\circ} \mathrm{C}$ on the mountains.

The average annual precipitation is estimated at around $800 \mathrm{~mm}$, varying from 600 to $900 \mathrm{~mm}$ along the coast and $1400 \mathrm{~mm}$ on the mountains. Precipitation from $2000 \mathrm{~m}$ altitude and snow melting, contribute to continuous flows of the watercourse during the drought.

In recent years, Lebanon suffered the consequences of the greenhouse effect which is increasingly felt by the population and vegetation.

The main changes observed in Lebanon in the dry season are:

a) Air pollution due to the accumulation of pollutants, as a consequence of a prolonged atmospheric stability;

b) The annual reduction in precipitation;

c) The delay in rains for several months and lengthening of the period of drought (from 4 to 7 months);

d) The drying up of water courses;

e) The torrential rainfall during the winter months which have negative consequences, such as the destruction of agricultural greenhouses, the erosion of soils and agricultural land, the floods in several cities located on the Lebanese coast;

\section{f) Lack of drinkable water.}

Water resources constitute a geopolitical and major economic issue in the Middle East; they represent a major environmental, social, and economic development parameter.

Mismanagement of watercourses contributes profoundly to the degradation of the lifestyle of Lebanese citizens.

Renewable resources in Lebanon have been evaluated by the Lebanese Ministry of water and energy at 2.7 billion $\mathrm{m}^{3}$ approximately in 2005 [1]. The population count was estimated in the same year at 4.8 million, with a $2.5 \%$ growth rate. These figures are no longer valid now due to a rapid increase in the number of the population in Lebanon. Since the outbreak of the civil war in Syria, the exact number of refugees who have fled the Syrian territory towards Lebanon is very difficult to assess, because the borders are not controlled at different points and because of the tangle of the Lebanese-Syrian territory. The number of Syrian refugees advanced by the press is a million and a half while the exact number probably exceeds this figure. This creates multiple problems: safety first, economic, health and social, including a shortage of water and power.

Streams in Lebanon undergo various kinds of pollution: litter, sewage due to a considerable discharges of urban and industrial waste water and agricultural waste etc.

*Corresponding author: Bouaoun Dunia, Department of Chemistry, Faculty of Sciences II, Lebanese University, Fanar, Lebanon, P.O. Box 90656, Tel: +9611681552 ; E-mail: Bouaoun_dunia@Yahoo.fr

Received April 07, 2016; Accepted April 30, 2016; Published May 09, 2016

Citation: Bouaoun D, Nabbout R (2016) Study of Physical and Chemical Parameters of Nahr Al Bared River, North Lebanon. J Coast Zone Manag 19: 426. doi:10.4172/2473-3350.1000426

Copyright: (c) 2016 Bouaoun D, et al. This is an open-access article distributed under the terms of the Creative Commons Attribution License, which permits unrestricted use, distribution, and reproduction in any medium, provided the original author and source are credited. 
Faced with this social and environmental difficult situation, we performed analytical traces, for 7 months from April to October, on three rivers in the region of Akkar, North Lebanon (Figure 1):
A) Nahr al-Bared
B) Aarka River
C) Oustouan River

In this article we are going to expose the results obtained for a single river "Nahr al Bared" (Figure 2).

Nahr al-Bared is a Lebanese river, $31 \mathrm{Km}$ long [2], fed by several springs at $1180 \mathrm{~m}$ altitude. At $20 \mathrm{Km}$ and $26 \mathrm{Km}$ from the source, two large dams stand to power hydroelectric plants and their deductions are used for sport and tourist activities [3].

It flows into the Mediterranean Sea at the level of Nahr al-Bared Palestinian refugee camp, less than $20 \mathrm{~km}$ from the Syrian border delimited by the Nahr al-Kabir. The water of this river, like several other rivers, is used for irrigation and as a discharge sewage and municipal waste (Figures 3 and 4).

The settings discussed in this article are:

- Meteorological study of the region of Akkar;

- $\mathrm{T}^{\circ} \mathrm{C}$, dissolved $\mathrm{O}_{2}, \mathrm{pH}$, conductivity;

- Calcium, Magnesium, carbonate, Nitrate, and sulfate;

- Heavy metals: iron, lead, mercury, Zinc, chromium, copper, Nickel, aluminum, Arsenic, Cadmium, Manganese, silver and Selenium.

The river of Nahr al-Bared represents a major source of water to several villages in north Lebanon. Analytical study should be done regularly to assess the quality of water and the possibility of use by population for agriculture, fisheries and other use.

\section{Sampling}

The sampling has been done properly in order to obtain analyses results which accurately reflect the quality of water. Samples have been collected and analyzed monthly, from April to October 2015, at various points along the river according to the accessibility of water and the nature of nearby agricultural and tourist activities. Some places are under military supervision banned to the public, such as the "Palestinian refugee camp". The methods of analysis are those defined by ISO and AFNOR.

Table 1 represents the distance from the source of Nahr al-Bared instead of the collection of the samples.

The Figure 2 represents a map of Nahr al-Bared River and the sampling stations.

\section{Equipment}

For the samples we used a rod with plastic bottles.

For analyses, the material used is Laboratory current equipment. A pH meter WTW 521 equipment with a combined electrode, a builtin thermometer and magnetic stirrer. Dissolved oxygen was measured using a device of land WTW multiline F/SET-3.A conduct meter: field LF 91 unit equipped with automatic temperature compensation. A SHIMADZU UV-Visible spectrophotometer has been used for colorimetric methods. Heavy metals were detected by using a SHIMADZU Atomic Absorption Spectrophotometer equipped with several lamps for specific detection.

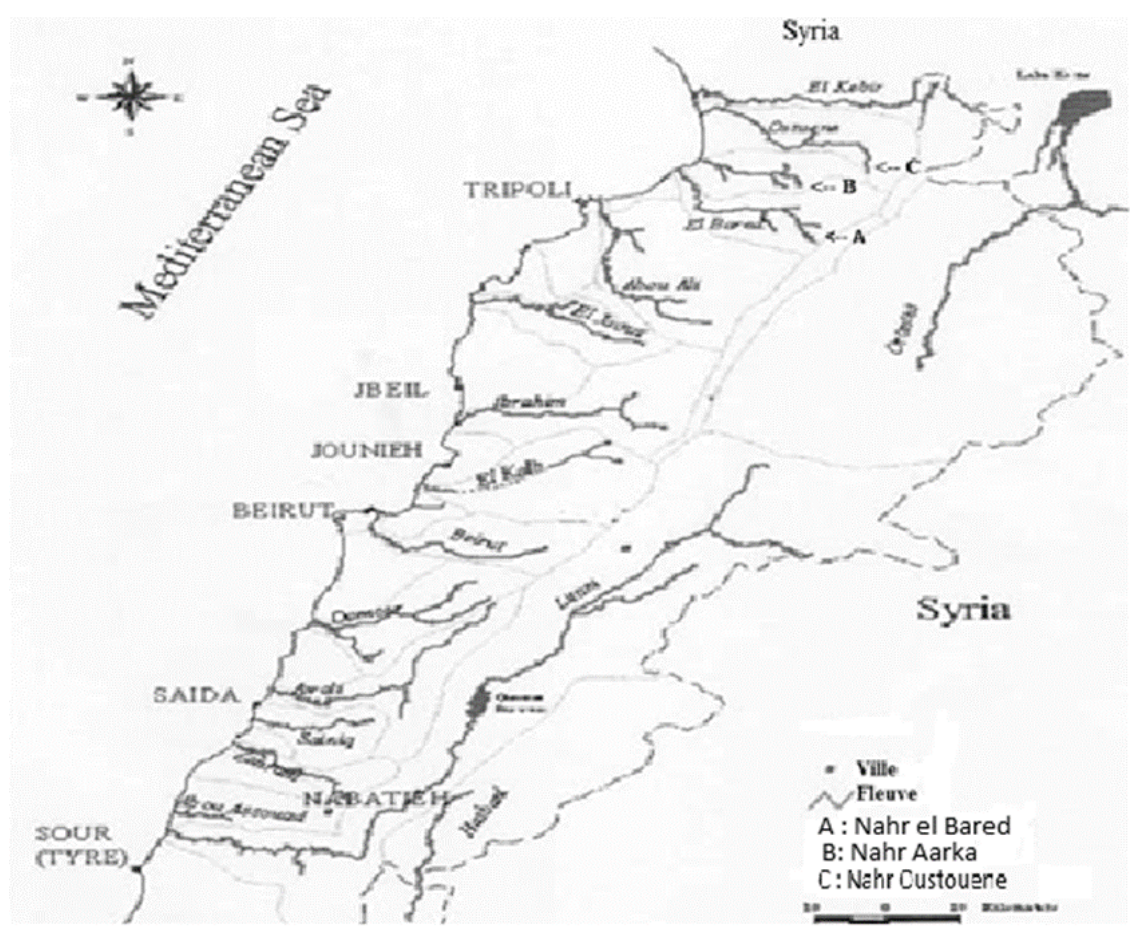

Figure 1: Hydric map of Lebanon and emplacement of the three studied rivers (Lebanese Ministry of Water and Energy). 


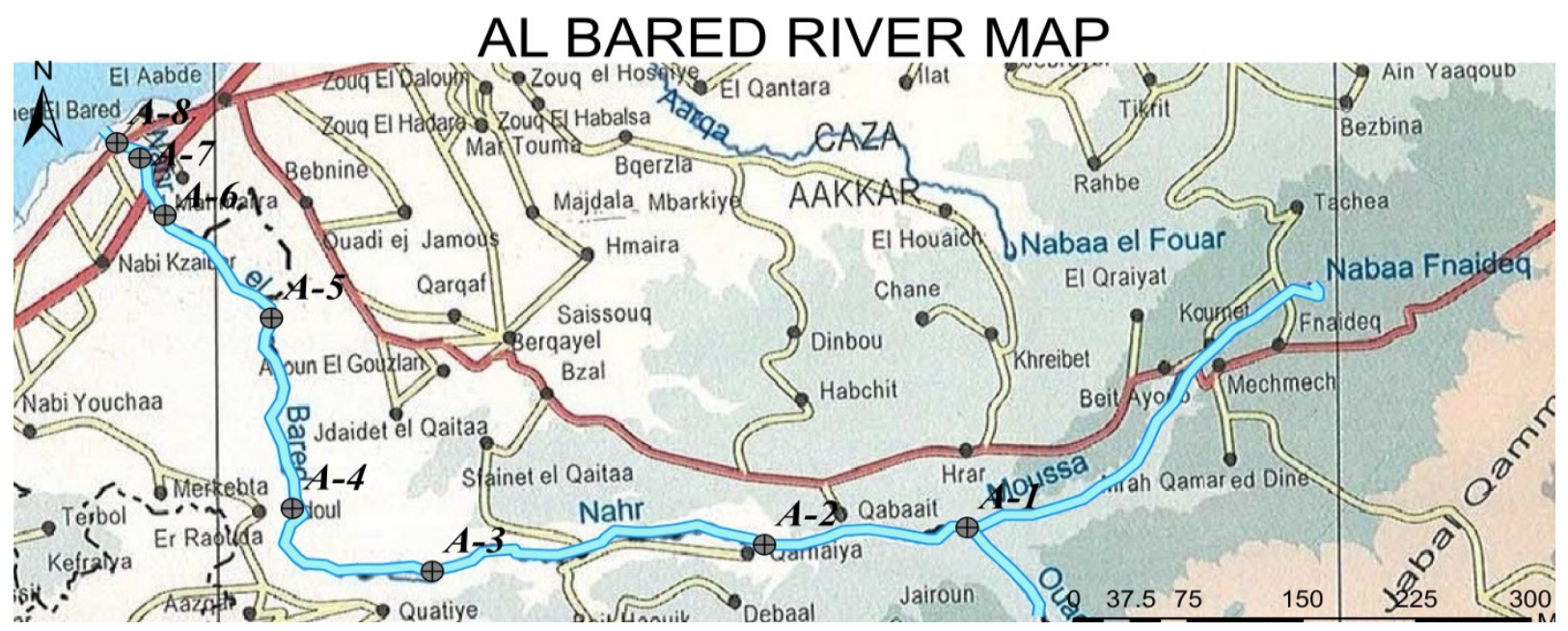

Figure 2: Sampling points from Nahr Al Bared River.

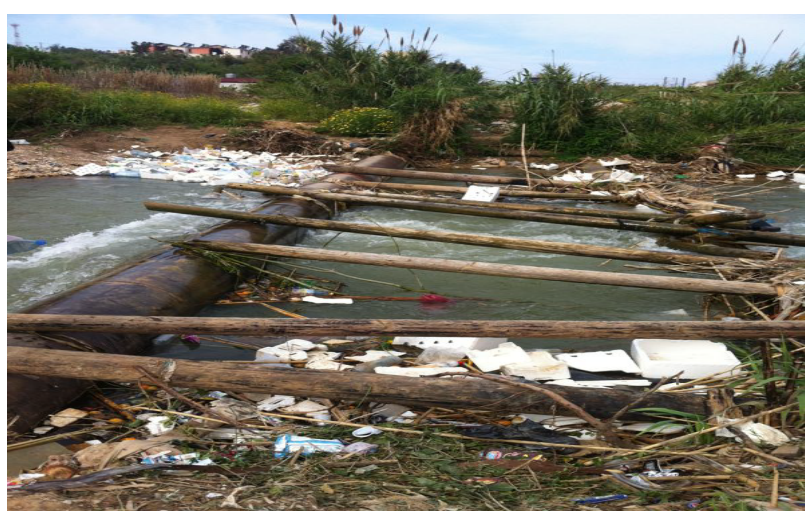

Figure 3: Unsightly View of Nahr al Bared River (Rony Nabbout, 2015).

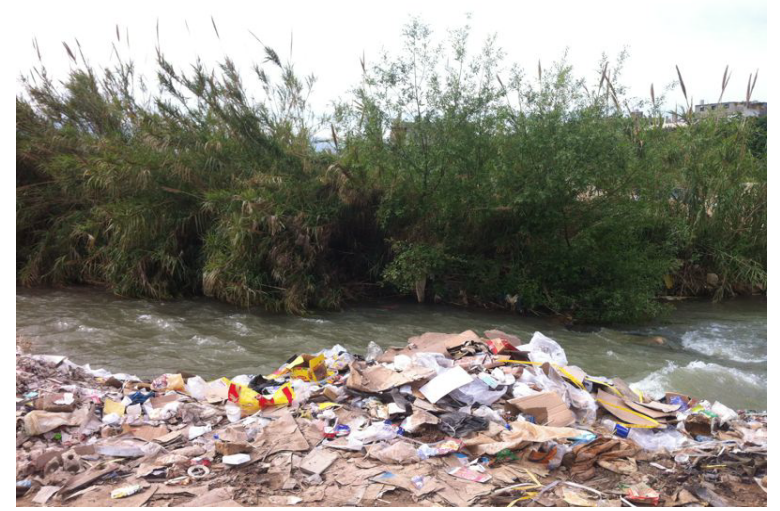

Figure 4: Wild landfill of waste on the edge of Nahr al Bared River (Rony Nabbout, 2015)

\section{Results and Discussion}

\section{Study of Akkar region weather}

During the period of analysis, atmospheric temperatures and precipitation fluctuated from one month to another. Table 2 represents the temperatures: maximum and minimum air and water temperatures and precipitation during the duration of the analysis. The rain did not exceed $125 \mathrm{~mm}$ during the 7 months of the study.

Air temperature has a direct effect on the evaporation of water, the concentration of pollutants, their diffusion in the air, their training in water or their dilution, dissolution in water and sedimentation at the bottom of the watercourse.

\section{Temperature}

Stream water temperatures generally range from $20^{\circ} \mathrm{C}$ in the mountains near the source to $32^{\circ} \mathrm{C}$ downstream. Table 2 shows average temperatures maximum in July and minimum in April. They vary proportionally to air temperature.

Average water temperatures ranged from $18-27^{\circ} \mathrm{C}$. They are compatible with microbial activities that can take place in the watercourse.

The water temperature has a direct effect on several parameters:

- Increase microbial activity in water and the biodegradation of nontoxic pollutants;

- Dissolved gases such as: dissolved oxygen, carbon dioxide dissolved etc.

- Acceleration of rates of the chemical and biochemical reactions by a factor of 2 to 3 for a temperature increase of $10^{\circ} \mathrm{C}$;

Decrease in dissolution of the carbonates of calcium with the increase of temperature.

Temperature of the water varies depending on air and the potential releases of industrial hot water. Abrupt changes in the values of temperature of more than $3^{\circ} \mathrm{C}$ are a disruptive factor on water.

\section{Dissolved oxygen}

As Dissolved Oxygen (DO) concentration is close to saturation, the 


\begin{tabular}{|c|c|c|c|c|c|c|c|c|}
\hline $\begin{array}{c}\text { Sampling } \\
\text { Points }\end{array}$ & A-1 & A-2 & A-3 & A-4 & A-5 & A-6 & A-7 & A-8 \\
\hline $\begin{array}{c}\text { Distance } \\
\text { from the } \\
\text { source (Km) }\end{array}$ & 9.70 & 16.0 & 21.70 & 22.70 & 27.50 & 28.60 & 29.50 & 31.00 \\
\hline
\end{tabular}

Table 1: Distance of the sampling from the source points.

\begin{tabular}{|c|c|c|c|c|}
\hline \multirow{2}{*}{ Month } & \multicolumn{2}{|c|}{ Temperature of air } & $\begin{array}{c}\text { Mean } \\
\text { Temperature } \\
\text { of water }\left({ }^{\circ} \mathbf{C}\right)\end{array}$ & $\begin{array}{c}\text { Precipitations } \\
(\mathbf{m m})\end{array}$ \\
\cline { 2 - 5 } April & 23 & 15 & 18 & 76 \\
\hline maxima $\left({ }^{\circ} \mathbf{C}\right)$ & minima $\left({ }^{\circ} \mathbf{C}\right)$ & 21 & 41 \\
\hline June & 27 & 17 & 24 & 0 \\
\hline July & 29 & 19 & 27 & 0 \\
\hline August & 30 & 22 & 26 & 0 \\
\hline September & 31 & 21 & 24 & 3 \\
\hline October & 27 & 21 & 22 & 5 \\
\hline
\end{tabular}

Table 2: Precipitation and average temperatures of air and water during the 7 months of analysis (weather station from Beirut International Airport).

ability of the River to absorb the pollution increases:

Sensitive fish species may be affected by an Oxygen content less than $4 \mathrm{mg} . \mathrm{L}^{-1}$

The origins of dissolved $\mathrm{O}_{2}$ in the studied streams are:

- Partial pressure in atmospheric $\mathrm{O}_{2}$

- The photosynthetic activity of aquatic plants.

Concentrations in dissolved oxygen vary in function of:

- Season and weather temperatures,

- The salinity of water,

- The brightness and the infiltration of sunlight,

- The agitation of the water,

- The availability of nutrient substrates,

- The rate of biodegradation of nutrients by microbial oxidation in the aquatic environment.

Rates of dissolved oxygen in the studied streams were around $2 \mathrm{mg}$ of $\mathrm{O}_{2} \mathrm{~L}^{-1}$ while according to Table 3 should be between 8.11 and 9.76 $\mathrm{mg}$ of $\mathrm{O}_{2}$. $\mathrm{L}^{-1}$

These values are due to microbial activities in waters contaminated by sewers, stagnant in the dry season and weakening of the water level. The largest decreases of the river dissolved oxygen concentration appear downstream from urban waste discharge.

Table 3 edits the decrease in the solubility of oxygen in water with increasing temperature [4].

\section{$\mathrm{pH}$}

$\mathrm{pH}$ is a parameter of importance to the quality of water and to aquatic life. Natural water must have a $\mathrm{pH}$ between 6.5 and 8.5. In most natural water bodies with a rate in high calcium, the $\mathrm{pH}$ value is fixed around 8.2 to 8.3 due to equilibrium between the concentrations of low acid carbonate (hydrogen carbonate) ions and carbonate resulting from dissociation of carbon dioxide in the water [5].

The Figure 5 describes the variation of $\mathrm{pH}$ of the samples, these

\begin{tabular}{|c|c|}
\hline $\mathbf{T}^{\circ} \mathbf{C}$ & Solubility $\mathbf{~} \mathbf{~ g}$ of $\mathbf{O}_{\mathbf{2}} \cdot \mathbf{L}^{-\mathbf{1}}$ \\
\hline 0 & 14.16 \\
\hline 5 & 12.37 \\
\hline 10 & 10.92 \\
\hline 15 & 9.76 \\
\hline 20 & 8.84 \\
\hline
\end{tabular}

Table 3: Decrease in the solubility of oxygen in water with increasing of temperature [4].

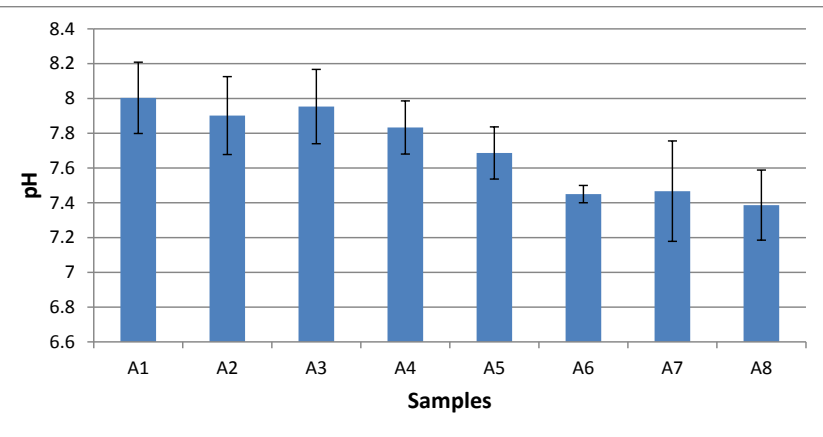

Figure 5: Variation of $\mathrm{pH}$ in different stations of Nahr al-Bared River.

values are consistent with high concentrations of carbonates in the waters of Nahr al-Bared river.

The $\mathrm{pH}$ of the water is determined by:

The nature of the land leached or crossed,

- The nature of wastewater effluents and their origins.

An acidic $\mathrm{pH}$ represents a high risk to the aquatic environment: if heavy metals exist, they are in an ionic form. A release of metals adsorbed on clay funds takes place in acidic medium.

Alkaline, ammonia concentrations constitute a high risk of toxicity to aquatic organisms.

$\mathrm{pH}$ has an important role in flocculation and coagulation treatment. The correction of the aggressive tendencies of water is carried out either by aeration, by adding calcium carbonate, or by filtration.

\section{Electrical conductivity}

Electrical conductivity expresses the ability of a solution to conduct electrical current. The water conductivity is commonly expressed in $\mu \mathrm{S} /$ $\mathrm{cm}$ (micro-Siemens per centimeter). Most of the mineral salts are good conductors. On the other hand, organic compounds are bad drivers. The conductivity of natural water is between 50 and $1500 \mu \mathrm{S} / \mathrm{cm} \mathrm{[4]}$.

Table 4 gives some information on the existing relationship between mineralization and conductivity [5].

Conductivity measured in the streams studied was very variable: during the months of April to July values ranged from 500 to $700 \mathrm{MS} /$ $\mathrm{cm}, 360 \mathrm{MS} / \mathrm{cm}$ at the level of the station A7 in the month of September and $1250 \mathrm{MS} / \mathrm{cm}$ at station A5 in October.

\section{Calcium}

Calcium is an essential compound for living bodies: skeleton of animal, teeth, shell eggs etc.

The guidelines of the Council of the European Communities 


\begin{tabular}{|c|c|}
\hline Conductivity $\boldsymbol{\mu S / \mathbf { c m }}$ & Mineralization \\
\hline$<100$ & Very low \\
\hline $100<$ cond $<200$ & Low \\
\hline $200<$ cond $<333$ & medium \\
\hline $333<$ cond $<666$ & Medium to high \\
\hline $666<$ cond $<1000$ & Important \\
\hline Cond $>1000$ & High \\
\hline
\end{tabular}

Table 4: Correlation between mineralization and conductivity [5].

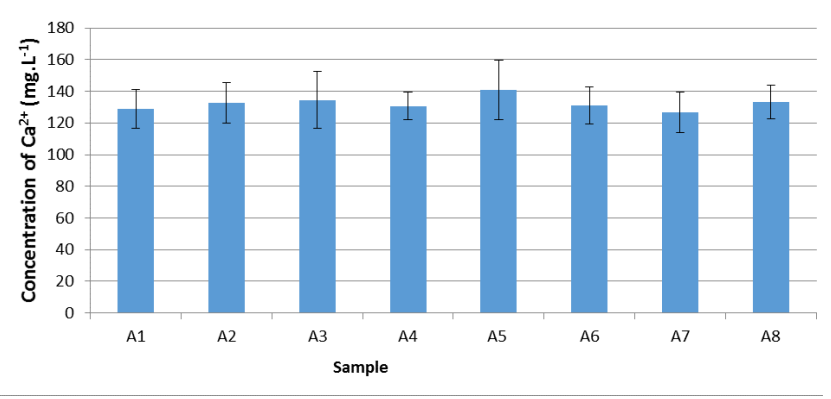

Figure 6: Concentration of calcium $\left(\mathrm{mg} \cdot \mathrm{L}^{-1}\right)$ in water of Nahr al-Bared River.

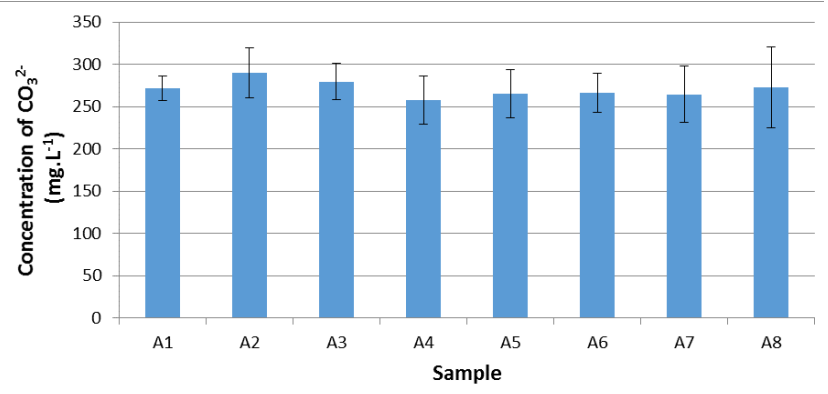

Figure 7: Concentrations of $\mathrm{CO}_{3}^{2-}\left(\mathrm{mg}^{-\mathrm{L}^{-1}}\right)$ of water of Nahr al-Bared River.

indicate as guide content of calcium in the water to a level of $100 \mathrm{mg} \cdot \mathrm{L}^{-1}$ [4].

In the studied streams, the Calcium concentration was very high due to Calcium-rich rocks of Akkar.

The Figures 6 and 7 describe respectively the concentrations of $\mathrm{Ca}^{2+}$ and $\mathrm{CO}_{3}^{2-}$ in the waters of the Nahr al-Bared (from $103.6 \mathrm{mg} \cdot \mathrm{L}^{-1}$ to $162 \mathrm{mg} \cdot \mathrm{L}^{-1}$ for $\mathrm{Ca}^{2+}$ and from 230 to $3716 \mathrm{mg} . \mathrm{L}^{-1}$ for $\mathrm{CO}_{3}^{2-}$ ). In all our samples, the levels remained higher than the limit value. The erosion of the limestone rocks is responsible for these high values.

\section{Magnesium}

Magnesium is the third most abundant structural metal in the crust, only preceded by aluminum and iron. According to the guidelines of the Council of the European communities, the content limit of $\mathrm{Mg}^{2+}$ equal to $30 \mathrm{mg} \cdot \mathrm{L}^{-1}$.

Concentrations of Magnesium in Nahr Al Bared from April to July are still much lower than the limit value. A few above the limit values were observed at the levels of the A4 and A8 stations in August. However, during the first three months of the study, i.e. from April to June, $\mathrm{Mg}$ concentrations were very low, not exceeding $8 \mathrm{mg} . \mathrm{L}^{-1}$ (Figure

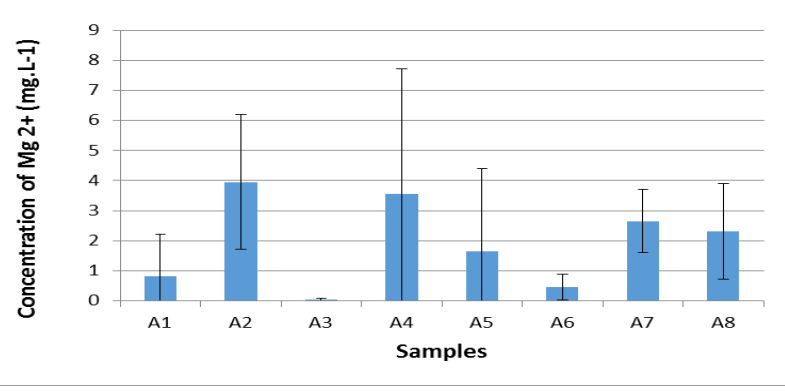

Figure 8: Concentrations of $\mathrm{Mg}^{2+}\left(\mathrm{mg}^{-\mathrm{L}^{-1}}\right)$ of water of Nahr al-Bared River.

8). During these three months, melting snow and high water flow were at the origin of the dilution effect of the magnesium concentrations.

Mg-rich rocks are the main sources of this mineral element in water; magnesium components are widely used in industry and agriculture.

The presence of cations of calcium and magnesium in natural water allows reducing the toxicity of metals due to the formation of metal complexes (by substitution of hydroxides).

\section{Nitrates}

Nitrates are salts dissolved from the oxidation of organic nitrogen in ammonium and nitrite with nitrous bacteria that oxidation under the action of nitric bacteria into nitrate. Wastewater discharged into Nahr al-Baredriver and fertilizer spread on agricultural land bordering it is at the origin of the concentrations found in the analyzed samples (Figure 9). The consequences on the balance of ecosystem are of various types:

- Physical: change in flow rate depending on whether the volume and frequency of releases are major and repeated,

- Physical-chemical: change of physical-chemical parameters of the original streams $(\mathrm{pH}$, temperature, dissolved oxygen, increased turbidity and suspended material, or even toxic substances eutrophic inputs, etc.),

- Biological: stress of the biocenosis that could lead to its disappearance and the eutrophication of the water course.

At the source of a watercourse, the nitrate content is very often between $0.05 \mathrm{mg} . \mathrm{L}^{-1}$ and then it rises gradually until a few mg.L $\mathrm{L}^{-1}$ along the river [5].

In the studied stream nitrate concentrations greatly exceed these values. Nitrate concentrations ranged from 2.24 to $9.32 \mathrm{mg} . \mathrm{L}^{-1}$ (Figure 9).

The environmental impact: Urban and industrial wastewater are the main agents of nitrogen pollution in, septic tanks, spills from farms, animal waste (including fish and birds) and the exhausts of cars. Nitrifying bacteria, in the presence of oxygen, convert organic nitrogen to ammonium and nitrite $\left[\mathrm{NO}_{2}^{-}\right]$then to nitrate $\left[\mathrm{NO}_{3}^{-}\right]$.

Nitrates as phosphates are at the origin of eutrophication beyond doses normally found in nature that change depending on the type of natural habitats. They often occur together in freshwater but also in waters brackish and salty closed or not renewed. Even at low concentrations (from 2 to $5 \mathrm{ppm}$ ) have, on some species of amphibians, chronic effects: reduced swimming, malformations during development.

\section{Sulfate}

Sulfates $\left(\mathrm{SO}_{4}^{2-}\right)$ can be found in almost all waters. The origin of most 


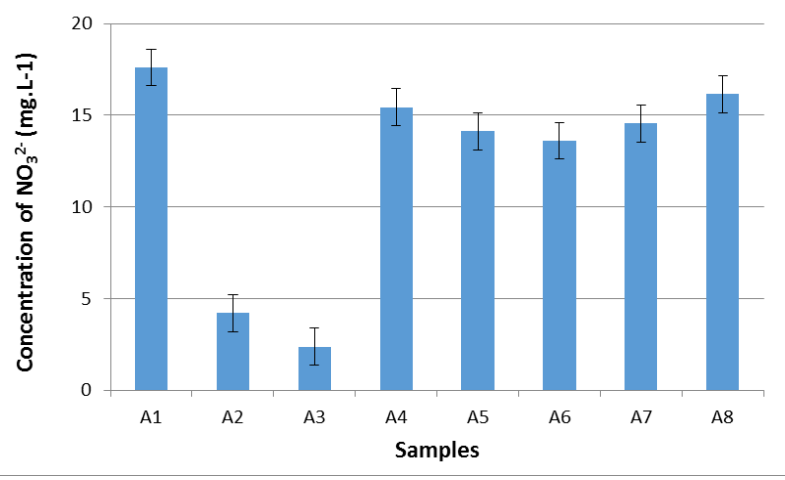

Figure 9: Concentration of $\mathrm{NO}_{3}^{-}\left(\mathrm{mg}^{\left.-\mathrm{L}^{-1}\right)}\right.$ of water of Nahr al-Bared River.

of the sulfate compounds is oxidation of sulfites, the presence of shale ores, or industrial waste.

Sulfate is one of the major elements of compounds dissolved in rainwater. Important concentrations of sulfate in the water we drink can have a laxative effect combined with calcium and magnesium, the two major components of the hardness of the water. Sulfates can be attacked by sulfate-reducing bacteria, which reduce hydrogen sulfide $\left(\mathrm{H}_{2} \mathrm{~S}\right)$. Some soils and some stones contain sulfate minerals. As groundwater moves through these, some sulfates are dissolved in the water.

Among the minerals that contain sulfate include sodium sulfate, magnesium sulfate, and calcium sulfate (gypsum).

Figure 10 describes different sulfate concentrations in Nahr el Bared river. The values obtained do not exceed $200 \mathrm{mg} . \mathrm{L}^{-1}$.

The concentration of sulfate in natural water is highly variable. In land not containing a significant proportion of sulfate mineral, it can reach $30 \mathrm{mg} . \mathrm{L}^{-1}$ to $50 \mathrm{mg} . \mathrm{L}^{-1}$.

The levels of Sulfate in the streams studied ranged at $124 \mathrm{mg} . \mathrm{L}^{-1}$ in April, station A4, and 198.7 mg. $\mathrm{L}^{-1}$ in August at the same station (Figure 8). These values are partially correlated to sulfate levels contained in the rocks. They are due to the agricultural activities nearby and the massive use of chemical fertilizers, pesticides and the leaching of sulfate (gypsum, calcium... sulfate).

High levels of sulfate are toxic to animals. Young animals consuming water with high sulfate concentrations can have severe diarrhea and in some cases they die. Like humans, animals tend to get used to heavily laden sulfate with time [6].

Sulfate gives a bitter taste, a medical water taste if it exceeds the concentration of $250 \mathrm{mg} . \mathrm{L}^{-1}$. This makes unpleasant water consumption. Important concentrations of sulfate can be corrosive to pipes particularly copper. In places where there are large concentrations of sulfate, it is common to use resistant to corrosion, such as plastic pipes [5].

Effect of sulfate on aquatic life: Sulfur, present in both animal and plant wastes, is converted to hydrogen sulfide (highly toxic) by anaerobic bacteria in medium which lacks oxygen. This acid itself is converted into sulfate in oxygenated environments [6].

\section{Heavy metals}

Unlike biodegradable organic pollutants, metals cannot be degraded biologically or chemically. They are bio accumulated in animal and plant organisms. Their half-life can be shorter or longer depending on

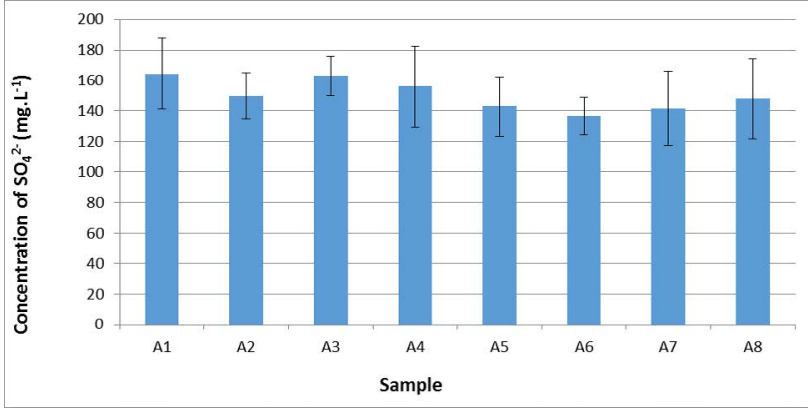

Figure 10: Concentration of $\mathrm{SO}_{4}^{2-}\left(\mathrm{mg}^{-\mathrm{L}^{-1}}\right)$ of water of Nahr al-Bared River.

the species concerned, the age of the body, and the level of activity of the individual. One of the most serious consequences of the persistence of metals is their accumulation in the food chain.

Metals or their compounds are often transported over large distances by air or water without undergoing transformations.

Many industrial products pollute surface waters:

- Agrochemical products,

- Waste,

- Aqueous effluents,

- Gaseous discharges,

- Thermal power plants,

- $\quad$ Steel industry

- The combustion of waste (incinerators),

- Traffic,

- $\quad$ Mineral fertilizers.

In the environment, a metal compound can only be transformed into other compounds where the metal will remain. In some cases, these are just such transformation reactions that lead to toxic compounds (e.g., methylation of mercury), or to a fixed asset (e.g., precipitation of lead sulfate $\mathrm{PbSO} 4$ ). In streams, they can bind to sediment clay at $\mathrm{pH}$ above 7 , that they are almost not driven by water.

Several minerals such as clay, metal oxides and humus compounds have loads to their surfaces with which metal ions can bind and thus become exchangeable. Because of the great diversity of the constituents of the soil, heavy metals are fixed to the solid phase of soils and sediments in different forms [7].

1. Form of exchangeable ions (such as Kaolinite or Montmorillonite clays-related).

2. Related by adsorption (surfaces, e.g., iron oxides).

3. Poorly soluble inorganic compounds.

4. There are in sediments and the bottom of water of metal ions that can break free and find the State dissolved during different chemical reactions in acidic.

Table 5 indicates the levels of heavy metals present in the waters Nahr el Baredriver. The values correspond to the limits of detection of the methodology. We noticed a lack of metal pollutants in the waters of the streams studied. Subsequent analyses will be performed to verify 


\begin{tabular}{|c|c|c|}
\hline Element & A1 & A2 \\
\hline iron $\left(\mathrm{mg} \cdot \mathrm{L}^{-1}\right)$ & $<0.01$ & $<0.01$ \\
\hline lead $\left(\mathrm{mg} \cdot \mathrm{L}^{-1}\right)$ & $<0.01$ & $<0.01$ \\
\hline Mercury $\left(\mu \mathrm{g} \cdot \mathrm{L}^{-1}\right)$ & $<1$ & $<1$ \\
\hline Zinc $\left(\mathrm{mg} \cdot \mathrm{L}^{-1}\right)$ & $<0.01$ & $<0.01$ \\
\hline Chromium $\left(\mathrm{mg} \cdot \mathrm{L}^{-1}\right)$ & $<0.01$ & $<0.01$ \\
\hline Copper $\left(\mathrm{mg} \cdot \mathrm{L}^{-1}\right)$ & $<0.01$ & $<0.01$ \\
\hline Nickel $\left(\mathrm{mg} \cdot \mathrm{L}^{-1}\right)$ & 0.02 & 0.01 \\
\hline Aluminum $\left(\mathrm{mg} \cdot \mathrm{L}^{-1}\right)$ & $<0.01$ & $<0.01$ \\
\hline Arsenic $\left(\mathrm{mg} \cdot \mathrm{L}^{-1}\right)$ & $<0.01$ & $<0.01$ \\
\hline Cadmium $\left(\mu \mathrm{mg} \cdot \mathrm{L}^{-1}\right)$ & $<1$ & $<1$ \\
\hline Manganese $\left(\mathrm{mg} \cdot \mathrm{L}^{-1}\right)$ & $<0.01$ & $<0.01$ \\
\hline Silver $\left(\mathrm{mg} \cdot \mathrm{L}^{-1}\right)$ & $<0.01$ & $<0.01$ \\
\hline Selenium $\left(\mathrm{mg} \cdot \mathrm{L}^{-1}\right)$ & $<0.01$ & $<0.01$ \\
\hline
\end{tabular}

$\mathrm{A} 1$ and $\mathrm{A} 2$ are samples at $3 \mathrm{Km}$ and 300 meters before the end flow of the river.

Table 5: Concentration of heavy metals in Nahr al- Bared River.

their absence also in sediments. The Nahr al-Bared River flows through a region poor in industries, except two hydropower plants whose activities stop as soon as the decrease in the flow of water during the dry season.

\section{Biological analysis}

A bacteriological analysis has been conducted by Khalaf et al. [3] Their study shows a rich presence of fecal Coliformes and Streptococcus fecalis all along Nahr al Bared River except at the source.

A. Dia and H. Dumont, 2011, have recorded 4 dragonfly species at Nahr al Bared River:

- Calopteryx. S. syriaca,

- Coenagrion scitulum,

- Pseudagrion syriacum,

- Anax imperator.

The discharge of wastewater is the main source of fecal Coliformes and Streptococcus fecalis.

\section{Conclusion}

Following all the analyses carried out on the River Nahr al-Bared, we can identify the following items:

- Although overall water quality is good, certain sections present an average to poor quality, often in connection with a significant reduction in natural flows.

- Discharges without treatment of wastewater of villages nearby cause a deterioration of the quality of the water downstream.

- It is important to take measures at the level of agricultural land in order to limit the source of hardly biodegradable pollutant. Equipment of farms of sufficient storage (pit or slurry) capacity will ensure that manure is applied during the growing season. We need to establish an area limit of $3 \mathrm{~m}$ wide along the watercourse to minimize leaching of fertilizers and pesticides products in the water of Nahr al-Bared.

-The impacts of hydroelectric development on the River are various: decrease of flows, sediment accumulation and disturbance of aquatic wildlife.
- In dry period, the possibilities of dissolution of the constituents of the waste dumped in the River are more reduced than in wet period;

- The risk of leaching from agricultural land which is rich in fertilizers is absent due to the negligible contribution of precipitation;

- The effects of dilution of chemicals are lower during the dry season than during the rain period;

- High concentrations of nitrate and sulfate denounce agricultural discharges in the studied river;

- Mineralization of water, measured by its electrical conductivity, is average in April and much accentuated in October. This State is a consequence of the decrease in the water level in streams resulting in a concentration of mineral elements present in the stream.

- Carbonate concentrations in the water of the river justify an alkaline $\mathrm{pH}$ close to 9 at certain points.

- The very low dissolved oxygen levels are due to stagnant state non-aerated water, to the enrichment of the waters of the River in sewage, their biodegradation increase consumption of oxygen and then decrease of its concentration in the water.

- $\mathrm{SO}_{4}{ }^{2-}$ and $\mathrm{Mg}^{2+}$ and anions $\mathrm{NO}_{3}{ }^{-}$are the characteristic elements of the Earth's crust. Their concentration in water depends essentially on their solubility. These elements do not give rise to reactions of hydrolysis and precipitation and their concentrations vary independently in water. With cations $\mathrm{K}^{+}, \mathrm{Na}^{+}$and anions $\mathrm{Cl}^{-}$, they constitute a parameter in the study of the quality of water.

-Heavy metal concentrations are negligible; they are accompanied by an alkaline $\mathrm{pH}$ which is no risk of leaching in case of adsorption on sediments. This point will be clarified in a subsequent search to be carried out on the sediments and their nature.

Recommendations should move towards an establishment of a network of monitoring and reduction of the polluting substances responsible for the change in the quality of the course of Nahr al-Bared. Regular analytical monitoring should allow a better appreciation of the water quality and better management of the streams studied. The establishment of sewage wastewater treatment contributes to relief of the watercourse in organic elements and better oxygenation of the water.

\section{References}

1. Comair $F$ (2008) Directeur Général des Ressources Hydrauliques et Electriques du Ministère de l'Energie et de l'Eau avec la collaboration de Brescia e Pavia, Università Degli Studi di Milano, Facoltà de Agraria. L'eau comme instrument de paix pour le développement rural.

2. Aref Dia, Henri J Dumont (2011) The Odonata of Lebanon. Zoology in the Middle East 52: 63-70.

3. Khalaf G, Slim K, Abi Ghanem C, Nakhlé K, Fakhri M (2009) Caractérisation et corrélation des paramètres biotiques et abiotiques des eaux du Nahr el Bared. Lebanese Science Journal: 10.

4. De Villiers J, Squilbin M, Yourassowsky C (2005) Qualité physico-chimique et chimiques des eaux de surface: cadre général. Les données de l'IBGE: «L'eau à Bruxelles».

5. Rodier J et coll (2005) L'analyse de l'eau: 1384.

6. Institut Bruxellois pour la Gestion de l'Environnement/Observatoire des Données de l'Environnement (2005) Qualité physico-chimique et chimique des eaux de surface: cadre général Fiche: 2.

7. Blieffert C, Perraud R (2001) Chimie de l'environnement; air, eau, sols, déchets De Boeck. 